\title{
Seasonal changes in spermatogenesis in the blue fox (Alopex lagopus), quantified by DNA flow cytometry and measurement of soluble $\mathrm{Mn}^{2+}$-dependent adenylate cyclase activity
}

\author{
A. J. Smith*, O. P. F. Clausen†, B. Kirkhus†, T. Jahnsen†, O. M. Møller* \\ and V. Hansson $\ddagger$ \\ * Department of Animal Husbandry and Genetics, The Norwegian College of Veterinary Medicine, \\ P.O. Box 8146 Dep., Oslo 1; †Institute of Pathology, Rikshospitalet, Pilestredet 32, Oslo 1; and \\ $\ddagger$ Institute of Medical Biochemistry, P.O. Box 1112, Blindern, Oslo 3, Norway
}

\begin{abstract}
Summary. The testes of the blue fox (Alopex lagopus) showed marked seasonal variations in size. Testicular weight and volume increased rapidly during January and February to reach maximal values by the beginning of the breeding season $(\sim 15$ March). During May and June the weights and volumes of the testes declined gradually to the quiescent state which lasted from July until October. Quantitation by DNA flow cytometry of the seasonal changes in the relative numbers of haploid (1C), diploid (2C) and tetraploid (4C) cell numbers in the testis showed that the increase in testis size from December to February was associated with a rapid expansion of the haploid cell compartment as spermatogenesis resumed. In addition, an increase in number of more mature cell types within the haploid cell population was observed over a 2-month period before the breeding season. The decline in testicular size from the middle of April until October was associated with a reduction in both the absolute and relative sizes of the haploid and tetraploid cell populations and a concomitant increase in the relative numbers of diploid cells. Measurements of the activity of the soluble $\mathrm{Mn}^{2+}$ dependent adenylate cyclase revealed seasonal variations that closely paralleled those of the haploid cell population, indicating that, as in other species, the enzyme may be associated with maturing germ cells.
\end{abstract}

\section{Introduction}

The blue fox (Alopex lagopus) is a seasonal breeder with a mating season of approximately 6 weeks from the middle of March until the end of April. There are few published reports on the reproductive physiology of this species, although detailed studies of reproductive function in the female are now becoming available (Møller, Mondain-Monval, Smith, Metzger \& Scholler, 1984). Studies on the male blue fox are limited to descriptions of the seasonal changes in ultrastructure of somatic and germ cells (Andersen, 1978a, b, c; Andersen, Sundby \& Hansson, 1981) and a few measurements of plasma testosterone concentrations (Andersen, 1978a; Nyberg, 1980) and testicular FSH binding capacity (Andersen et al., 1981) at different times of the year. Such studies have so far only been performed in a limited number of animals.

DNA flow cytometry has previously been used to monitor the proportions of haploid (1C), diploid (2C) and tetraploid (4C) cells in the testes of developing rats (Clausen, Purvis \& Hansson, 1977 ) and in fine-needle biopsies from human cases of infertility (Gordeladze, Åbyholm, Cusan, Clausen \& Hansson, 1982a). The testicular cytosol from rat and human testes contains a soluble $\mathrm{Mn}^{2+}$-dependent adenylate cyclase (EC 4.6.1.1). This enzyme is associated predominantly with 
spermatids, although some activity has been found in the primary spermatocyte compartment (Gordeladze, Purvis, Clausen, Rommerts \& Hansson, 1981).

The aim of the present study was to examine the seasonal changes in the size and cellular composition of the testis of the blue fox by DNA flow cytometry and to investigate to what extent these seasonal changes are associated with alterations in soluble $\mathrm{Mn}^{2+}$-dependent adenylate cyclase activity.

\section{Materials and Methods}

\section{Animals}

The 50 males used in this study were 2-4 years of age and were individually housed under natural conditions of daylength and temperature on the Research Farm for Furbearing Animals, Heggedal, Norway. The foxes were fed a ration of standard Norwegian wet feed (the main components being fish, slaughterhouse offal and concentrates) and were given water ad libitum. The length of the mating season is defined as the period between the dates of the first and last matings on the farm.

Collection of testis material. At approximately monthly intervals from November 1981 to October 1982 (as shown in Text-fig. 1), 4 males were anaesthetized with intravenous pentobarbitone sodium and castrated. In 6 animals (November 1981) the testes were removed at pelting, $\sim 20 \mathrm{~min}$ after death. The testes were measured with calipers, weighed, cut into small pieces and immediately frozen on solid $\mathrm{CO}_{2}$, before storage at $-70^{\circ} \mathrm{C}$ until assay. Measurements of testis length (2a) and width (2b) were converted to volumes (V) by means of the formula for a prolate spheroid, $\mathrm{V}=1.33 \pi \mathrm{ab}^{2}$ (Wildt, Baas, Chakraborty, Wolfle \& Stewart, 1982). Values obtained during the same calendar month were pooled, and calculations were made of mean and s.e.m.

In addition, testicular volume was measured through the scrotum for 4 intact males from May 1982 to April 1983. Values of length (which included the head of the epididymis) and width were converted to volumes using the formula described above. No allowance was made for scrotal skin thickness. Mean values for the two testes were then calculated.

DNA flow cytometry. Testicular tissue stored at $-70^{\circ} \mathrm{C}$ was prepared for DNA flow cytometry as described by Vindeløv, Christensen \& Nissen (1983). Briefly, the tissue was minced and dispersed in citrate buffer and exposed to a solution containing trypsin, detergent and spermine for $10 \mathrm{~min}$ at room temperature. A solution containing trypsin inhibitor and RNAase was added before staining with the fluorochrome propidium iodide. This treatment resulted in the production of essentially clean nuclei. The nuclei were then excited at $488 \mathrm{~nm}$ (effect $200 \mathrm{~mW}$ ) and fluorescence in the red spectrum $(>630 \mathrm{~nm}$ ) was measured in a cytofluorograph (Model $50 \mathrm{H}$ ) with cell sorting capability connected to a Model 2150 computer unit (Ortho Instruments, Westwood, MA, U.S.A.). Mouse lymphocytes functioned as diploid controls. Histograms were constructed to show the relative numbers of cells with haploid, diploid and tetraploid fluorescence. To take into account the seasonal changes in testicular size, the relative numbers $(\%)$ of cells in each DNA population were then multiplied by testis weight to give arbitrary values for the number of cells per testis. In addition, the variation in nuclear size within each DNA population was evaluated by plotting forward light scatter against fluorescence.

Cell sorting. Samples of nuclei were sorted from the hypofluorescent haploid and haploid regions of fluorescence intensity and collected on glass slides for morphological examination (nuclear shape, size and chromatin staining pattern).

Preparation of testicular cytosol. Pooled testicular material was homogenized in 20 volumes of Tris-EDTA buffer (10 ml Tris-HCl, $1 \mathrm{mm-EDTA,} \mathrm{pH} \mathrm{7 \cdot 5)}$ for $2 \times 10 \mathrm{sec}$ at $0^{\circ} \mathrm{C}$. The homogenates 
were then filtered (pore size $100 \mu \mathrm{m}$ ) and centrifuged at $10000 \mathrm{~g}$ and $4^{\circ} \mathrm{C}$ for $30 \mathrm{~min}$. The supernatant was centrifuged further at $106000 \mathrm{~g}$ and $4^{\circ} \mathrm{C}$ for $60 \mathrm{~min}$. The supernatant from the second centrifugation was then used for assay of soluble $\mathrm{Mn}^{2+}$-dependent adenylate cyclase activity.

Assay for soluble $\mathrm{Mn}^{2+}$-dependent adenylate cyclase activity. In the present study, $30 \mu \mathrm{l}$ aliquants of testicular cytosol were added to $20 \mu \mathrm{l}$ incubation medium. The final assay mixture contained cytosol (49-64 $\mu$ g protein), ATP (0.7 mM), [ ${ }^{32}$ P]ATP $\left(2.3 \times 10^{6}\right.$ c.p.m. $), \mathrm{Mn}^{2+}(10 \mathrm{mM})$, cAMP (1 mM), [8- $\left.{ }^{3} \mathrm{H}\right]$ cAMP (11 000 c.p.m.), EDTA (1.6 mM) and an ATP-regenerating system providing $0.02 \mathrm{mg}$ myokinase $/ \mathrm{ml}, 0.2 \mathrm{mg}$ creatine kinase $/ \mathrm{ml}$ and $20 \mathrm{~mm}$-creatine phosphate. The mixtures were incubated at $35^{\circ} \mathrm{C}$ and the assay terminated by adding $100 \mu \mathrm{l}$ of a "Stop solution" containing cAMP (10 mM), ATP (40 mM) and sodium dodecyl sulphate $(1 \%)$, mixing and immersing the tubes in ice. The reaction mixtures were stored at $-20^{\circ} \mathrm{C}$ until successive elution through Dowex $50-\mathrm{X} 4$ and alumina oxide columns to isolate cAMP. The final imidazole eluates $(4 \mathrm{ml})$ were added to scintillation fluid $(5 \mathrm{ml})$ and counted for $5 \mathrm{~min}$.

All activities were corrected for overall assay recovery and allowance made for overlap between the ${ }^{32} \mathrm{P}$ and ${ }^{3} \mathrm{H}$ channels. Activities were then multiplied by testis weight to give arbitrary figures for activity per testis. A more detailed investigation of the soluble $\mathbf{M n}^{2+}$-dependent adenylate cyclase activity in the blue fox testis, including enzyme viability, assay requirements and kinetic properties, has been published elsewhere (Smith, Jahnsen, Attramadal \& Hansson, 1984).

Miscellaneous. ATP concentrations were measured by u.v.-light spectrophotometry at $260 \mathrm{~nm}$. Protein concentrations were estimated by the method of Lowry, Rosebrough, Farr \& Randall (1951) after hydrolysis in $\mathrm{NaOH}$ at $60^{\circ} \mathrm{C}$ for $30 \mathrm{~min}$ and using BSA as the standard. Least-squares regression analysis was used to examine the relationships between the various measurements. Independent means were tested for difference by the two-sample Student's $t$ test.

\section{Results}

\section{Testicular weight and volume}

The seasonal changes in testicular weights are shown in Text-fig. 1 (a). Testicular weights were lowest during July and August but increased rapidly during December and January to reach maximal values by March. Individual variations were most noticeable during the phases of testicular redevelopment and regression (e.g. January: range 2.5-4.8 g; May: range 2.5-4.7 g) and were considerably less at the beginning of the mating season (March: range 6.7-8.0 g). Likewise, individual testicular weights during the quiescent phase were similar (July: range $1 \cdot 4-2 \cdot 1 \mathrm{~g}$; August: range $1 \cdot 2-1 \cdot 7 \mathrm{~g}$ ). The calculated values of testicular volume displayed a parallel curve and there was a good correlation between testicular volume and testicular weight $(r=0.93$, Text-fig. 1b).

Text-figure 2 shows the seasonal changes in testicular volume in 4 intact foxes. There were considerable individual differences in maximal testicular size, but testicular development and regression appeared to be well synchronized.

\section{Fluorescence distributions}

Examples of recordings from testes collected at four times of the year are shown in Text-fig. 3. The left panels show the relative numbers of cells with haploid, diploid and tetraploid fluorescence intensity (corresponding approximately to 200,400 and 800 units respectively). The right panels show the variations in forward light scatter (mainly a reflection of nuclear size) for each intensity. In the testes of animals castrated between August and December (Text-fig. 3a, left panel), almost all the pulses had a diploid fluorescence intensity (400) and very few pulses were located in 


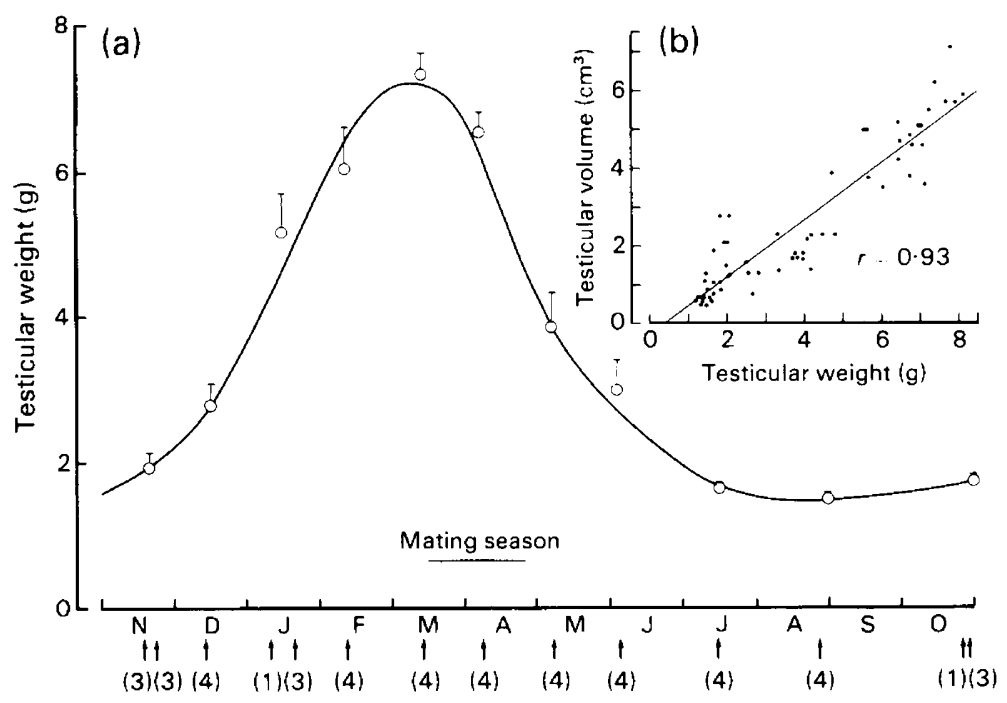

Text-fig. 1. (a) Testicular weights of 46 blue fox males castrated from November 1981 to October 1982. The arrows depict the dates of castration and the figures in parentheses indicate the number of animals castrated on each date. Values are means \pm s.e.m. of all the animals castrated in a given month. (b) Relationship between testicular weight and volume.

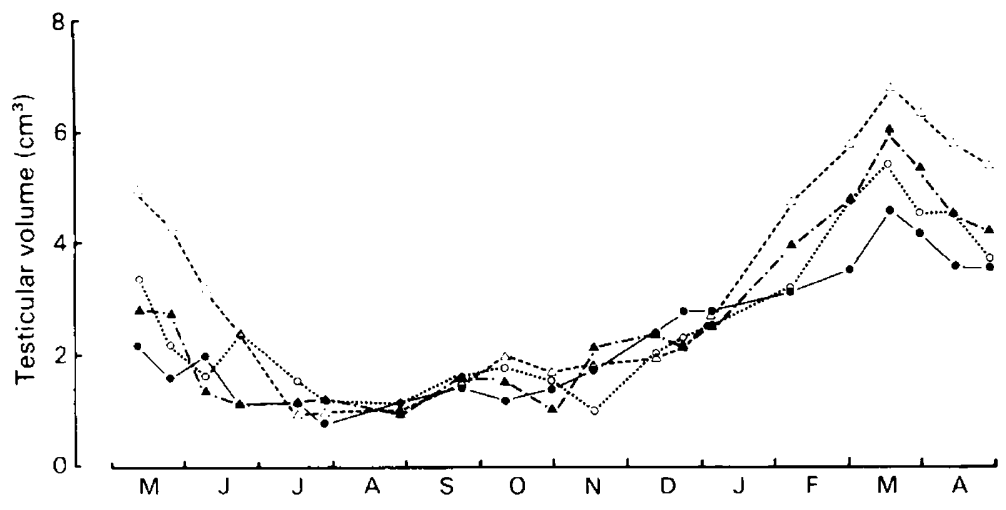

Text-fig. 2. Seasonal changes in testicular volume of 4 blue fox males measured from May 1982 until April 1983. Values are means of the two testes.

the haploid (200) and tetraploid (800) regions. The right panel shows that there was a high degree of forward light scatter amongst the diploid cells. In December (Text-fig. 3b), small peaks were present in the tetraploid and haploid regions (left panel), indicating the onset of the completion of meiosis. The right panel shows that, although there were variations within the compartments, the mean forward scatter of the diploid cells lay between that of the haploid and tetraploid populations. In January (Text-fig. 3c) there was a further increase in the proportion of pulses in the haploid region, and also an increase in number of hypofluorescent haploid cells. The proportion of tetraploid cells was about the same as in December.

Fluorescence distributions characteristic for the mating season (March-April) are shown in Text-fig. 3(d). There was a further increase in the number of hypofluorescent haploid pulses. 
(a)

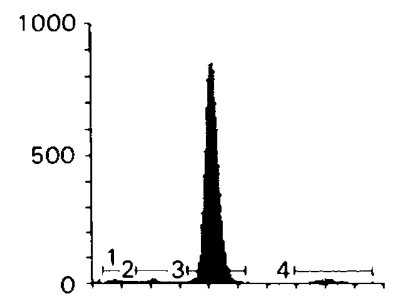

(b)

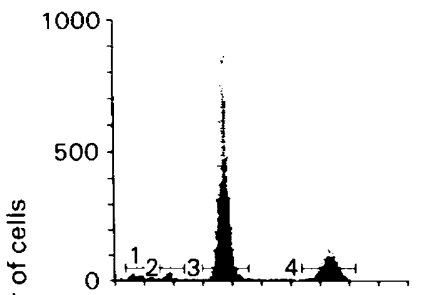

(c)

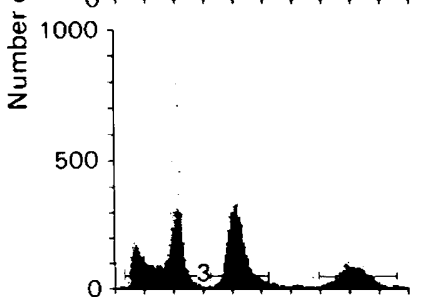

(d)

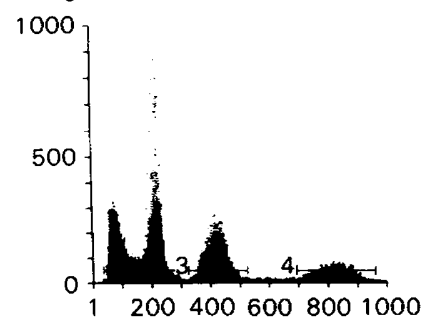

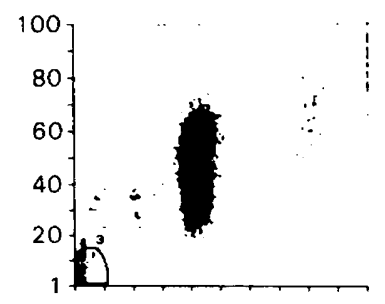
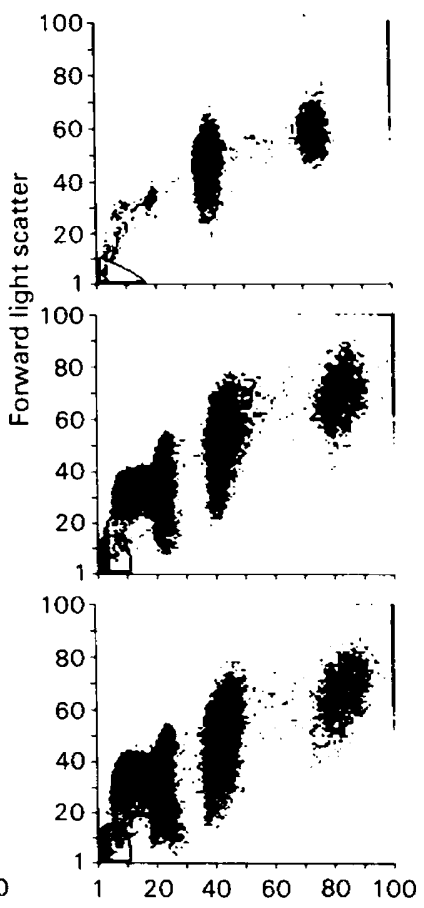

Relative DNA fluorescence intenisity

Text-fig. 3. Fluorescence distributions (left-hand panels) and plots of fluorescence versus forward light scatter (right-hand panels) typical for (a) August, (b) December, (c) January and (d) March. The numbers on the left panels show the approximate positions of fluorescence associated with total haploid $(1+2)$, diploid (3) and tetraploid (4) cells. Pulses in the areas labelled ' 3 ' on the right-hand panels are mainly debris and background noise and have been gated out from the corresponding DNA histograms (left-hand panels).

\section{Cell sorting}

Pulses from the low scatter and low fluorescence regions (areas labelled " 3 " on the right panels in Text-fig. 3) were caused by cell debris and background noise. They were therefore subtracted from the DNA histograms (left panels). Cell nuclei sorted from the hypofluorescent haploid peak (which constituted about $25 \%$ of all the haploid cells) were elongated and had the morphology of nuclei from spermatozoa. There was no apparent morphological difference between nuclei from the low- or high-scatter regions of this peak. Nuclei sorted from the area between the hypofluorescent haploid peak and the haploid peak were also mainly elongated, but some showed abnormalities and others stained uniformly dark. Those with a high degree of forward scatter were mainly nuclei of round spermatids, whereas those showing less scatter were elongated spermatids. Cells from the major haploid peak had round nuclei consistent with the morphology of round spermatids. 


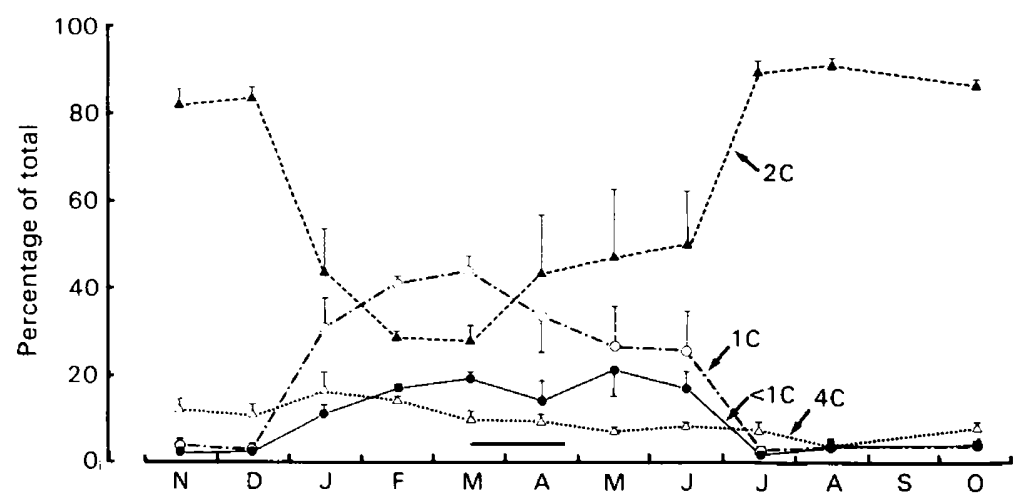

Text-fig. 4. Seasonal variations in the relative numbers of hypofluorescent haploid $(<1 C)$, haploid (IC), diploid (2C) and tetraploid (4C) cell populations in the blue fox testis. Values are means \pm s.e.m. for all the males castrated in a given month (see Text-fig. 1). The horizontal bar indicates the mating season.
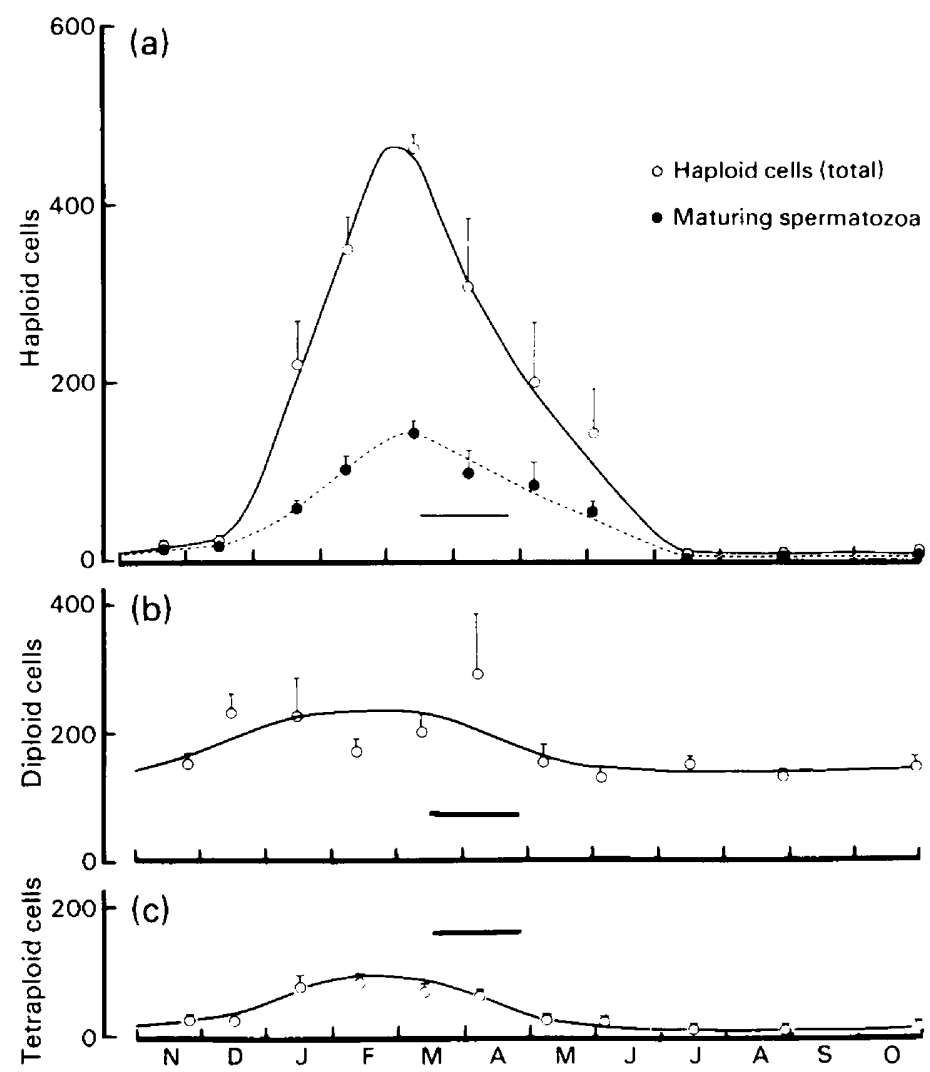

Text-fig. 5. Seasonal variations in the testicular content of (a) haploid cells, (b) diploid cells and (c) tetraploid cells. Values are means \pm s.e.m. for all the animals castrated in a given month (see Text-fig. 1). Correlation coefficient of testis weight to total haploid cell numbers, $r=0.97$. The horizontal bars indicate the mating season. 
Relative seasonal variations in the cell populations

A summary of the circannual variations in the relative proportions of cells with haploid, diploid and tetraploid fluorescence is shown in Text-fig. 4. The composite haploid compartment increased abruptly in size from around $7 \%$ in December to a peak of more than $60 \%$ around March just after the relative peak in the tetraploid compartment and when the diploid compartment was at a minimum.

\section{Absolute seasonal variations in the cell populations}

Text-figure 5 shows the seasonal variations in numbers of haploid, diploid and tetraploid cells after correction for testis weight. It is clear that the marked increase in testis weight from December to April (Text-fig. 1a) was largely due to the increase in number of haploid cells per testis. There were, however, also smaller but significant $(P<0.01)$ increases in the mean numbers of diploid and tetraploid cells during the same period.

Soluble $\mathrm{Mn}^{2+}$-dependent adenylate cyclase activity

The activity of the soluble germ cell-specific adenylate cyclase expressed per testis is shown in Text-fig. 6. Very low levels were observed from July to November after which activity increased rapidly during January and February to reach peak values by March and April. A rapid decline in activity was observed during May and June. The seasonal variations in soluble adenylate cyclase activity were virtually identical to those of the haploid cell population in the testes (Text-fig. 5a, $r=0.97)$.

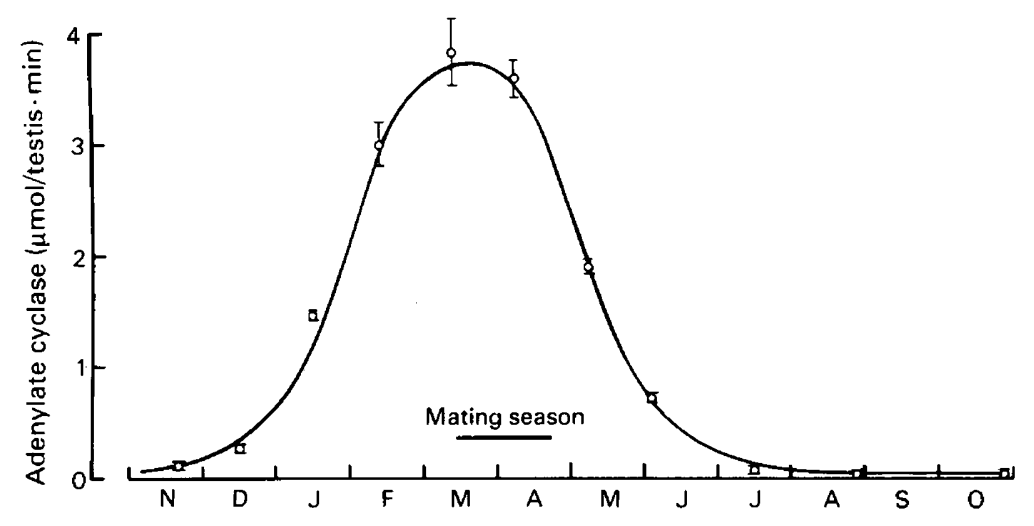

Text-fig. 6. Seasonal variations in total testicular activity of the soluble $\mathrm{Mn}^{2+}$-dependent adenylate cyclase. Values are means \pm s.e.m. for all the animals castrated in a given month (see Text-fig. 1). The correlation coefficients $(r)$ of enzyme activity with testicular weight and haploid, diploid and tetraploid cell numbers per testis were $0.97,0.97,0.57$ and 0.81 respectively.

\section{Discussion}

In the present study we have demonstrated considerable seasonal changes in both the size and cellular composition of the blue fox testis, which are closely associated with variations in the activity of the soluble $\mathrm{Mn}^{2+}$-dependent adenylate cyclase. In addition, we have shown that DNA 
distributions of high resolution can be obtained from frozen testicular material from the blue fox and that DNA flow cytometry may be used to quantify the circannual variations in the size of the haploid and tetraploid compartments, both in terms of relative numbers and also arbitrarily expressed as cell numbers per testis.

Quantitation by DNA flow cytometry of the seasonal changes in the numbers of haploid, diploid and tetraploid cells showed that the increase in testicular weight from December to February is associated with a rapid expansion of the haploid cell compartment as spermatogenesis resumes (Text-fig. 5a). The diploid and tetraploid compartments, however, also show a smaller but significant increase in size during this period (Text-figs $5 \mathrm{a} \& 5 \mathrm{~b}$ ). Since these cells have an individual mass that is greater than that of the haploid cells, it is likely that they also contribute to the increase in testicular weight.

The formation during spermatogenesis of primary spermatocytes, which give rise to the majority of cells in the tetraploid population (Clausen et al., 1979), is to some extent masked by the accumulation of haploid cells within the testis due to the long maturation time in the haploid compartment. Nevertheless, an increase $(P<0.01)$ in tetraploid cell numbers was observed during January preceding the haploid cell peak (Text-figs $5 \mathrm{~b} \& 5 \mathrm{c}$ ).

The small circannual changes in the size of the composite diploid compartment (Text-fig. 5b) indicate stability in the total number of diploid cells (germ cells and somatic cells) during the year. This is consistent with previous qualitative histological studies on the male blue fox (Andersen, 1978a; Andersen et al., 1981) which suggest that, although the somatic cell population shows seasonal changes in ultrastructure, the total number of cells is fairly constant in the adult animal.

In the rat, three distinct subpopulations of haploid cells have been distinguished on the basis of differences in the fluorescence intensity of stained nuclear DNA (Clausen, Parvinen \& Kirkhus, 1982). Reduction in fluorescence intensity of the haploid cells was associated with spermatid maturation. In the present study, cell sorting confirmed that the haploid cells with low fluorescence intensity (Text-figs 3c \& 3d) were germ cells that were more mature than the rest of the haploid population. The present method of preparation can therefore be used to differentiate subgroups of haploid cells by means of their degree of maturation.

A close relationship has been found between the presence of spermatids and adenylate cyclase activity in the testis of the rat, mouse and man (Gordeladze et al., 1981, 1982a,; Gordeladze, Parvinen, Clausen \& Hansson, 1982b). However, some enzyme activity is also associated with the primary spermatocyte compartment (Gordeladze et al., 1981). The correlations observed in the present study between enzyme activity and the haploid and tetraploid cell populations, and the poor correlation to diploid cell numbers (Text-fig. 6) are in agreement with these earlier findings. Measurement of soluble $\mathrm{Mn}^{2+}$-dependent adenylate cyclase activity in testicular biopsies may therefore provide an index of spermatogenic activity in this seasonal breeder.

The good correlation between testicular weight and volume $(r=0.93$; Text-fig. $1 \mathrm{~b})$ shows that linear testis measurements can be used on the intact animal to assess the size of the testis. However, the individual variations (Text-fig. 1b) in testicular weight for a given volume (and vice versa) emphasize the need for serial measurements on the same animal if linear measurements are to be used for assessing the development of the testis. The good correlation of testicular weight to haploid cell numbers $\left(r=0.97\right.$; Text-fig. 5a) and soluble $\mathrm{Mn}^{2+}$-dependent adenylate cyclase activity $(r=$ 0.97 ; Text-fig. 6) also indicate that serial linear measurements on individual male blue foxes may be used to assess the state of testicular maturation.

Measurements of testis weight/volume, cell composition by DNA flow cytometry and adenylate cyclase activity are therefore all of value in describing the seasonal variations in the spermatogenic epithelium in blue foxes.

We thank Tone Varaas, Jostein Haugstad and Jon Morstøl for skilled technical assistance and Aslaug Skiaker for typing the manuscript. This study was supported by the Norwegian Furbearers Association. 


\section{References}

Andersen, K. (1978a) Seasonal change in fine structure and function of Leydig cells in the blue fox (Alopex lagopus). Int. J. Androl. 1, 424-439.

Andersen, K. (1978b) Fine structure of spermatogonia and spermatocytes in the blue fox (Alopex lagopus). Acta vet. scand. 19, 229-242.

Andersen, K. (1978c) Fine structure of developing spermatids used as a basis for staging of the spermateleosis in the blue fox (Alopex lagopus). Zentbl. VetMed. C. Anat. Histol. Embryol. 7, 164-181.

Andersen, K., Sundby, A. \& Hansson, V. (1981) Fine structure and FSH binding of Sertoli cells in the blue fox (Alopex lagopus) in different stages of reproductive activity. Int. J. Androl. 4, 570-581.

Clausen, O.P.F., Purvis, K. \& Hansson, V. (1977) Application of micro-flow fluorometry to studies of meiosis in the male rat. Biol. Reprod. 17, 555-560.

Clausen, O.P.F., Purvis, K. \& Hansson, V. (1979) Endocrine correlates of meiosis in the male rat. Archs Androl. 2, 59-66.

Clausen, O.P.F., Parvinen, M. \& Kirkhus, B. (1982) Stage-related variations in DNA fluorescence distribution during rat spermatogenic cycle measured by flow cytometry. Cytometry 2, 421-425.

Gordeladze, J.O., Purvis, K., Clausen, O.P.F., Rommerts, F.F.G. \& Hansson, V. (1981) Cellular localization of the $\mathrm{Mn}^{2+}$-dependent adenylyl cyclase $(\mathrm{AC})$ in rat testis. Int. J. Androl. 4, 172-182.

Gordeladze, J.O., Abyholm, T., Cusan, L., Clausen, O.P.F. \& Hansson, V. (1982a) Cellular localization of the $\mathrm{Mn}^{2+}$-dependent adenylyl cyclase $(\mathrm{AC})$ in the human testis. Archs Androl. 8, 199-204.
Gordeladze, J.O., Parvinen, M., Clausen, O.P.F. \& Hansson, V. (1982b) Stage-dependent variation in $\mathrm{Mn}^{2+}$-sensitive adenylyl cyclase (AC) activity in spermatids and $\mathrm{FSH}$-sensitive $\mathrm{AC}$ in Sertoli cells. Archs Androl. 8, 43-51.

Lowry, O.H., Rosebrough, N.J., Farr, A.L. \& Randall, R.J. (1951) Protein measurement with the folin phenol reagent. J. biol. Chem. 193, 265-275.

Meller, O.M., Mondain-Monval, M., Smith, A., Metzger, E. \& Scholler, R. (1984) Temporal relationships between hormonal concentrations and the electrical resistance of the vaginal tract of blue foxes (Alopex lagopus) at pro-oestrus and oestrus. J. Reprod. Fert. 70, $15-24$.

Nyberg, K. (1980) Crossing blue fox (Alopex lagopus) to red fox (Vulpes vulpes) using artifical insemination. Nord. VetMed. 32, 132-138.

Smith A.J., Jahnsen, T., Attramadal, H. \& Hansson, V. (1984) Soluble $\mathrm{Mn}^{2+}$-dependent adenylate cyclase activity in the testis of the blue fox. Archs Androl. (in press).

Vindelov, L.L., Christensen, I.J. \& Nissen, N.I. (1983) A detergent-trypsin method for the preparation of nuclei for flow cytometric DNA analysis. Cytometry 3, 323-327.

Wildt, D.E., Baas, E.J., Chakraborty, P.K., Wolfle, T.L. \& Stewart A.P. (1982) Influence of inbreeding on reproductive performance, ejaculate quality and testicular volume in the dog. Theriogenology 17, 445452.

Received 24 February 1984 